\title{
Effects of Pre-deformation Annealing on Mechanical Properties of Ti-Based Amorphous Alloys
}

\author{
Zhao Yanchun ${ }^{1,2}$, Ma Wenlong ${ }^{1,2}$, Zhao Zhiping ${ }^{1,2}$, Huang Mingyuan ${ }^{1,2}$, Kou Sheng- \\ zhong $^{1,2}$, Li Chunyan ${ }^{1,2}$, Yuan Zizhou ${ }^{1,2}$ \\ ${ }^{1}$ State Key Laboratory of Advanced Processing and Recycling of Non-ferrous Metals, Lanzhou University of Technology Lanzhou 730050, \\ China; ${ }^{2}$ Wenzhou Research Institute of Pump and Valve Engineering of Lanzhou University of Technology, Wenzhou 325105, China
}

\begin{abstract}
Ti}_{40} \mathrm{Ni}_{40} \mathrm{Cu}_{20}$ amorphous matrix composite plate specimens were fabricated by the levitation suspend melting-water cooled $\mathrm{Cu}$ mold process. The specimens were pre-compressed at different degrees with a universal testing machine and then annealed at $150{ }^{\circ} \mathrm{C}$ for $30 \mathrm{~min}$. The effects of pre-deformation annealing processes on the microstructure and mechanical properties of $\mathrm{Ti}_{40} \mathrm{Ni}_{40} \mathrm{Cu}_{20}$ alloy system were studied by a metallographic microscope, X-ray diffraction (XRD) and scanning electron microscope (SEM). The results show the martensitic phase transformation that of the austenite phase under external force occurs. The phase transition induced by the deformation coupled with the annealing release of residual thermal stress plays a role in enhancing both strength and toughness of the amorphous matrix composite. Both martensite phases and austenite phases are increased with the increase with the degrees of pre-deformation increasing, and martensite phases are increased faster. Thus, the yield strength of the composite increases, while the ductility declines. Therefore the controllable yield strength in the pre-compression stage for shaping can be realized.
\end{abstract}

Key words: Ti-based amorphous composites; mechanical properties; ductility

Amorphous Alloys (also known as Glassic Alloys or Noncrystalline Alloys) are metals in the undefined structure without fixed form, so as to exhibit high strength, high toughness, excellent corrosion resistance, soft magnetic properties, etc ${ }^{[1]}$. Their corrosion resistance and wear resistance are also excellent compared with those of crystalline alloys or stainless steel materials of the same composition. Other crystalline materials cannot be compared with these amorphous metallic alloys, thus making them promising metal materials. However, amorphous alloy materials have a fatal flaw in which their ductility (also plasticity) is relatively low to be prone to abrupt rupture, which restricts the development and application of amorphous alloys.

In the early 1960's Duwez Research Team had first prepared amorphous alloys which were cooling Au-Si alloys at a high rate ${ }^{[2]}$. The crystalline ribbons and other structures had been prepared during a series of experiments in the following years. It was found from the research on the mechanical properties and fracture mechanism of amorphous alloys that the advantages of amorphous alloys are remarkably different from those of metallic crystalline materials and the amorphous alloys tend to exhibit a quasi-brittle fracture behavior along a single shear band ${ }^{[3-5]}$. This drawback restricts its application in the field of structural materials, and to improve the plastic deformation behavior of amorphous alloys has become an important research orientation. Ever since then researchers have been devoting to improving such a drawback in many aspects. For example, the effect of the cooling rates on the microstructure and mechanical properties of bulk amorphous alloys was studied. And the effect of adding micro-elements on the amorphous forming ability and

Received date: September 14, 2016

Foundation item: National Natural Science Foundation of China (51551101); Natural Science Foundation of Zhejiang Province of China (LQ13E010002); Science and Technology Program of Lanzhou (2014-2-9); Young Teacher Training Program of Lanzhou University of Technology (Q201406)

Corresponding author: Zhao Yanchun, Ph. D., Associate Professor. State Key Laboratory of Advanced Processing and Recycling of Non-ferrous Metals, Lanzhou University of Technology, Lanzhou 730050, P. R. China, E-mail: yanchun_zhao@163.com 
mechanical properties were also investigated ${ }^{[6]}$. It then turned out that the amorphous forming ability and mechanical properties could be further improved ${ }^{[7]}$. And the in-situ crystalline phase reinforced BMGCs were prepared by suction-casting methods under the supercooling conditions, while involved the effect of high-temperature relaxation on the structural evolution and mechanical properties of the BMGCs therein, as well as the variation in the microstructure in the isothermal annealing treatment process and its influence on the mechanical properties ${ }^{[8,9]}$.

The plastic deformation ability of amorphous alloys is related to the control of shear deformation and the number of shear bands ${ }^{[10-12]}$. Plasticity can be effectively improved by the prefabrication of multiple shear bands. The formation of multiple shear bands and the slip branching and cross blocking of the shear band effectively prevent the brittle fracture of the amorphous alloy along main shear band ${ }^{[13]}$.

In this paper, the effect pre-deformation annealing treatment on mechanical properties of $\mathrm{Ti}_{40} \mathrm{Ni}_{40} \mathrm{Cu}_{20}$ titanium-based amorphous composite materials was studied. The water cooled copper hearth levitation melting master alloy was used in the study, and then, $\mathrm{Ti}_{40} \mathrm{Ni}_{40} \mathrm{Cu}_{20}$ amorphous alloy plate samples were prepared by suction casting into a copper. Then the samples underwent a pre-compression by compressor to different degrees, followed by an annealed treatment at $150{ }^{\circ} \mathrm{C}$ for $30 \mathrm{~min}$. The effect of the pre-deformation annealing treatment on the microstructure and the mechanical behaviors of the sample was investigated.

\section{Experiment}

The nominal composition of the main sample employed in the experiment is $\mathrm{Ti}_{40} \mathrm{Ni}_{40} \mathrm{Cu}_{20}$, which was prepared accurately by the mass ratio of each of constituents in the alloy and the ratio was stoichiometrically calculated according to the atomic percentages. The purities of $\mathrm{Ti}, \mathrm{Ni}$ and $\mathrm{Cu}$ were all higher than 99.99\%. After that, the master alloy ingots were prepared with the levitation copper mold. The alloy plate samples were prepared by a copper mold suction casting process after smelting repeatedly three times or more to keep the components homogeneous. The samples experienced the precompression by a compression-testing machine at different levels of compression, and then they were treated by annealing at $150{ }^{\circ} \mathrm{C}$ for $30 \mathrm{~min}$. The optical microstructure and structure of the alloy sample prepared were characterized mainly by metallographic microscope $\mathrm{MeF}_{3}$ and powerful sputtering target D/Max-2400 X-ray diffraction (XRD) $(\mathrm{Cu} \mathrm{K} \alpha$ radiation, $40 \mathrm{kV}, 30 \mathrm{~mA}$ ). Again, the sample was compressed on the domestic WDW-100D testing machine for testing its mechanical properties, and its compression fracture morphology was observed with the JMS-6700F scanning electron microscope (SEM).

\section{Results and Discussion}

\subsection{XRD analysis on $\mathrm{Ti}_{40} \mathrm{Ni}_{40} \mathrm{Cu}_{20}$ amorphous alloys}

As shown in Fig.1, there is a trend towards forming amorphous diffuse peaks from $45^{\circ}$ to $50^{\circ}$. The results show that the precipitated phases are the $\mathrm{B} 2-\mathrm{Ti}(\mathrm{Ni}, \mathrm{Cu})$ and the B19'- Ti(Ni,Cu). The B2-Ti(Ni,Cu) structure is a super-cooled austenitic phase depending on its plasticity; whereas the B19'$\mathrm{Ti}(\mathrm{Ni}, \mathrm{Cu})$ structure is a martensite phase with respect to its strength. The austenite phase under the action of external force could lead to the stress induced martensite phase transformation, thus making the strain hardening, namely, the 'deformation induced phase transformation' to enhance the toughness of the amorphous matrix ${ }^{[14-15]}$. Both martensite phases and austenite phases are increased with the increase in the degrees of pre-deformation, but martensite phases are increased faster. While the pre-deformation is $2.5 \%$, as there is no martensitic transformation in the elastic deformation stage, the crystal phases change little, compared with the untreated phase. From the theory about the phase transformation induced by deformation and the release of the residual stress, we found that both $\mathrm{B}_{2}-\mathrm{Ti}(\mathrm{Ni}, \mathrm{Cu})$ phase and $\mathrm{B} 19$ ' $-\mathrm{Ti}(\mathrm{Ni}, \mathrm{Cu})$ phase are increased with the increase in pre-deformation amount. However, the pre-compression at the plastic deformation stage results in the partial transformation of B2-Ti $(\mathrm{Ni}, \mathrm{Cu})$ austenite phase to $\mathrm{B} 19^{\prime}-\mathrm{Ti}(\mathrm{Ni}, \mathrm{Cu})$ martensite phase. Thus, martensite phases are increased faster. Consequently, the strength of the alloy increases, whereas the plasticity decreases.

\subsection{Microstructure of $\mathrm{Ti}_{40} \mathbf{N i}_{40} \mathrm{Cu}_{20}$ amorphous alloys}

Fig. 2 illustrates the as-cast microstructure of the $\mathrm{Ti}_{40} \mathrm{Ni}_{40^{-}}$ $\mathrm{Cu}_{20}$ ternary alloy. A crystal phase is formed from the different cooling rates in the cooling process during which the copper mold directly contacts with the outer wall of the plate sample. From the surface to the center of the sample, different crystal structures are formed on the amorphous matrix due to the different cooling rate of solidification. Acicular martensite formed by rapid cooling, and the gradually increased austenite dendrite can be observed in Fig. 2a. In Fig.2b there are also more acicular martensite phases, but more austenite phases

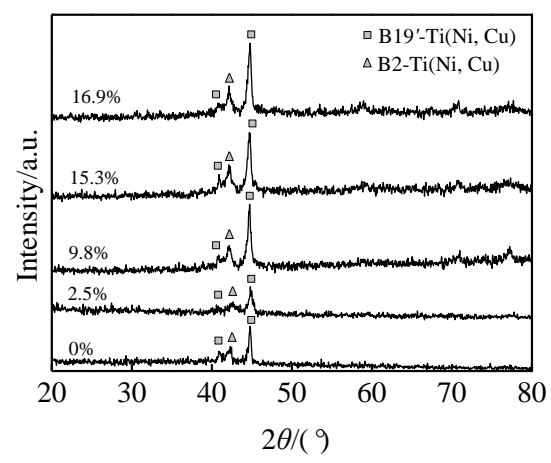

Fig.1 XRD patterns of $\mathrm{Ti}_{40} \mathrm{Ni}_{40} \mathrm{Cu}_{20}$ alloy samples with different predeformation before annealing at $150{ }^{\circ} \mathrm{C}$ for $30 \mathrm{~min}$ 


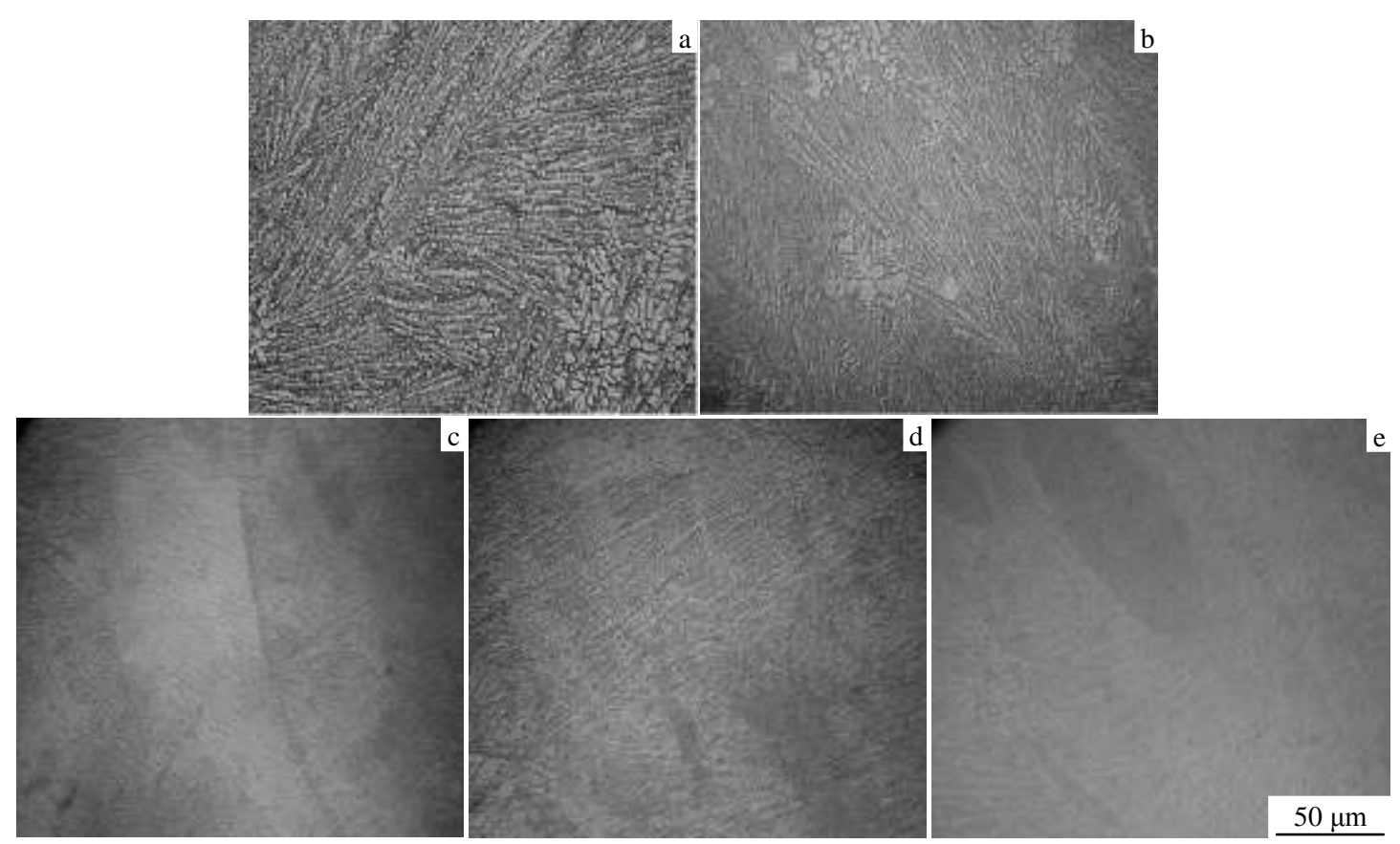

Fig.2 Metallographs of $\mathrm{Ti}_{40} \mathrm{Ni}_{40} \mathrm{Cu}_{20}$ amorphous alloy with different predeformation/annealing treatments: (a) $0 \%$, (b) $2.5 \%$, (c) $9.8 \%$, (d) $15.3 \%$, and (e) $16.9 \%$

than in Fig.2a. As can be seen from Fig.2c 2e, acicular martensites are arranged in a denser manner, and also, the austenites are present only in a small amount. Such results are consistent with XRD analysis.

\subsection{Mechanical properties of $\mathrm{Ti}_{40} \mathbf{N i}_{40} \mathrm{Cu}_{20}$ amorphous alloys}

The situ precipitated plastic phase, shape memory alloy supercooled austenite phase $\mathrm{B}_{2}-\mathrm{Ti}(\mathrm{Ni}, \mathrm{Cu})$ in bulk metallic glass matrix can result in a martensite transformation phase under applied stress loading so as to enhance both strength and toughness of glass substrate ${ }^{[14-16]}$. As can be seen from Fig. 3 and Table 1, with increasing the amount of precompression, its yield strength increases gradually, and in turn, the plasticity declines gradually. While the amount of predeformation is set at $25 \%$, the work hardening behavior is the

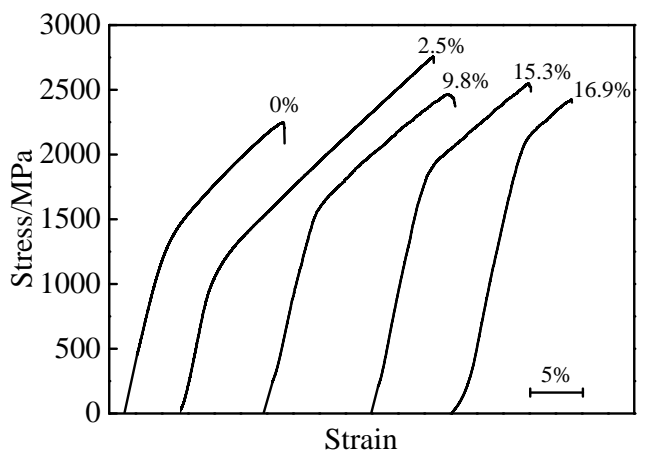

Fig.3 Compression stress-strain curves at room temperature for $\mathrm{Ti}_{40} \mathrm{Ni}_{40} \mathrm{Cu}_{20}$ alloy samples after various predeformation/ annealing processes
Table 1 Mechanical properties of $\mathrm{Ti}_{40} \mathrm{Ni}_{40} \mathrm{Cu}_{20}$ alloy samples after different predeformation/annealing processes

\begin{tabular}{cccc}
\hline $\begin{array}{c}\text { Deformation } \\
\text { amount/\% }\end{array}$ & $\begin{array}{c}\text { Yield } \\
\text { strength/MPa }\end{array}$ & $\begin{array}{c}\text { Fracture } \\
\text { strength/MPa }\end{array}$ & $\begin{array}{c}\text { Plastic } \\
\text { strain/\% }\end{array}$ \\
\hline 0 & 1237 & 2247 & 11.4 \\
2.5 & 984 & 2745 & 21.5 \\
9.8 & 1462 & 2464 & 13.5 \\
15.3 & 1691 & 2545 & 9.4 \\
16.9 & 1950 & 2428 & 6.1 \\
\hline
\end{tabular}

most obvious, thus showing its strongest plasticity. Then, its plasticity in the elastic deformation stage is enhanced gradually with increasing the amounts of predeformation, representing the strength being gradually increased. The function of annealing is to release the internal stress from materials. The strength increases after annealing, which is also verified as compared with Fig. 4.

\subsection{Fracture morphology of $\mathrm{Ti}_{40} \mathrm{Ni}_{40} \mathrm{Cu}_{20}$ amorphous alloys}

The experimental sample fracture after the pre-deformation for annealing treatment and compression testing was scanned, and then the resulting fracture morphology patterns were analyzed. Thus, the influence of the different pre-compressions for annealing on the fracture morphology was identified, and then the fracture mechanism and fracture behavior of titanium-based amorphous composites were revealed.

Fig.5 presents compressive fracture morphology of the samples pre-compressed $\left(150^{\circ} \mathrm{C}\right.$ for $\left.30 \mathrm{~min}\right)$ at different Levels. In Fig.5a, in addition to the main shear band and a few small shear bands, the main shear plane still shows the veined 


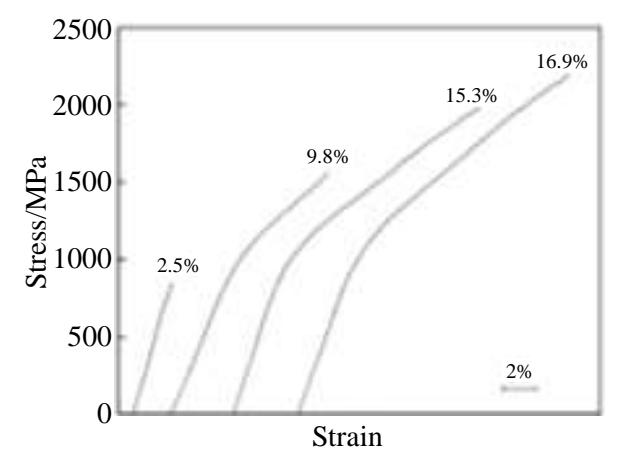

Fig.4 Compression stress-strain curves at room temperature for $\mathrm{Ti}_{40} \mathrm{Ni}_{40} \mathrm{Cu}_{20}$ alloy samples with different predeformations patterns resulting from the expansion of shear band, it is not easy to develop a catastrophic abrupt rupture. The continuous dense veined fracture surfaces present in Fig.5b, and it is the typical fracture morphology characteristic of amorphous alloys. The density of veined patterns may affect the materials' strength and plasticity change. In other words, the smaller the veined patterns and the higher the density, the better the material properties such as plasticity ${ }^{[17]}$. As can be seen from Fig.5c, 5d and 5e, with the increase of pre-deformation amounts, veined patterns decrease instead, showing that various fractures are linked to each other to gradually form step- like platforms and burrs, thereby indicating the plasticity is lowered. In Fig.5e, despite ups and downs on the cleavage, the section looks flat and smooth, without previous various

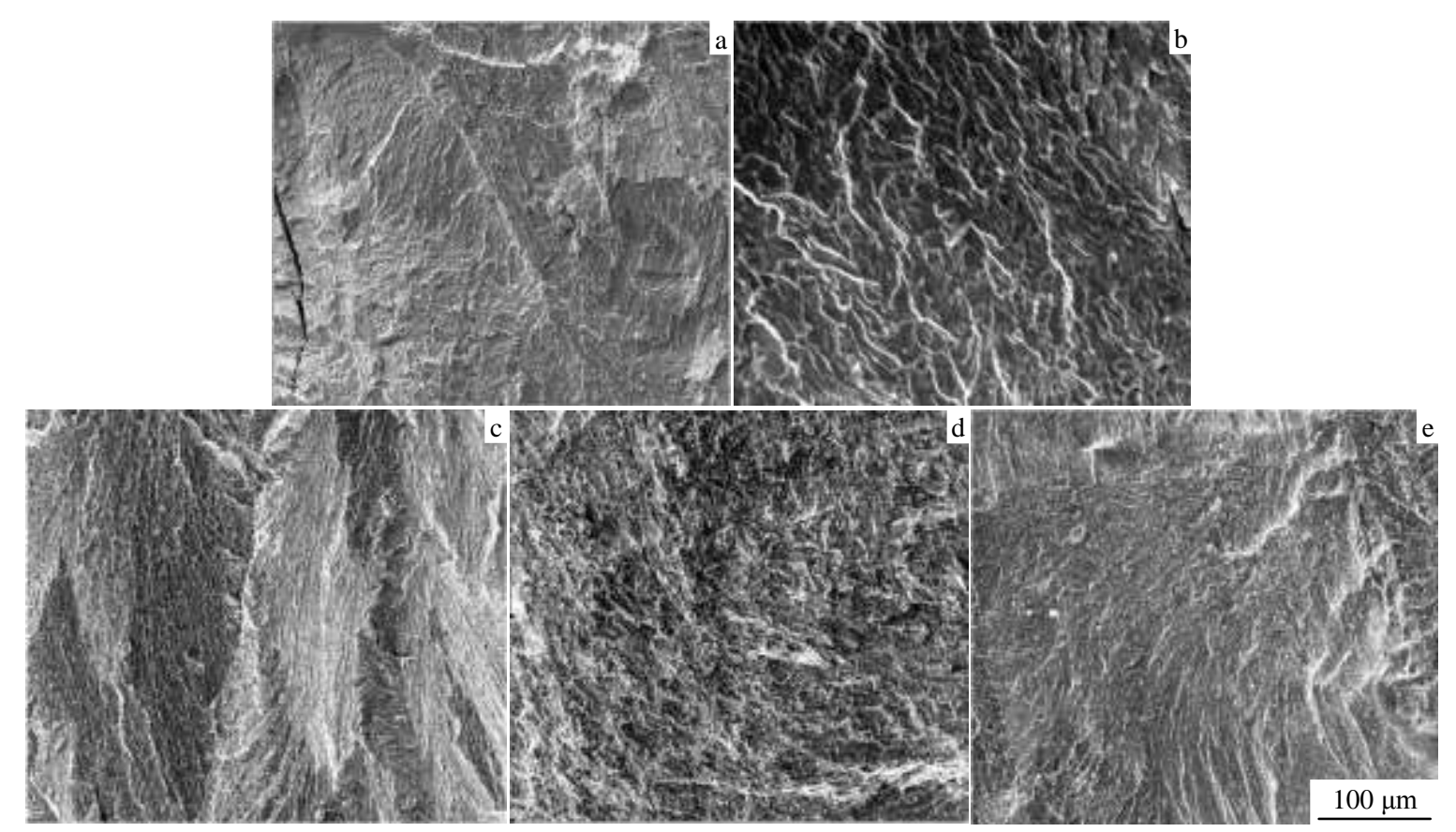

Fig.5 Compressive fracture morphologies of the samples with different predeformations amount ( $150^{\circ} \mathrm{C}$ for $\left.30 \mathrm{~min}\right)$ : (a) $0 \%$, (b) $2.5 \%$, (c) $9.8 \%$, (d) $15.3 \%$, and (e) $16.9 \%$

veined patterns and/or brittle fractures. It can be seen that the plasticity is rather small. The feature of fracture morphology is consistent with the mechanical property tendency. The sample pre-compressed by $2.5 \%$ deformation exhibits the best plasticity. And as the pre-deformation increases, the yield strength increases gradually, while the ductility decreases ${ }^{[18-20]}$.

As a whole, the plasticity and toughness of the material increase gradually in the case of increasing the predeformation. The largest plastic deformation takes place on pre-deforming at $2.5 \%$ since the material is at the stage of elastic deformation.

\section{Conclusions}

1) The predeformation and annealing can change the mechanical properties of titanium based amorphous composites. With increasing the amount of precompression, overall the yield strength is on the rise, the plasticity is reduced. However, the general performance is superior to that of the sample prior to the treatment.

2) When increasing the amount of deformation, the phase transformation is induced by deformation, and transformation of the austenite phase in the amorphous matrix into martensite phase occurs, which lead to an increase in strength of materials, thus lowering plasticity. When the amount of predeformation is up to $2.5 \%$, no phase transformation takes place due to still at the stage of elastic deformation; as a result, the plastic strain reaches $21.5 \%$, and the fracture strength is $2745 \mathrm{MPa}$, indicating the best comprehensive performance of 
the material.

3) Predeformation in the shaping stages can bring the yield strength under control.

\section{References}

1 Inoue A. Materials Transactions[J], 1995, 36: 86

2 Clement W, Willens R H, Duwez P. Nature[J], 1960, 1879(3): 869

3 Das J, Tang M B, Kim K B et al. Physical Review Letters[J], 2005, 94: 205501

4 Hofmann D C. Science[J], 2010, 329: 1294

5 Spaepen F A. Acta Metallurgica[J], 1977, 25(4): 407

6 Argon A S. Acta Metallurgica[J], 1979, 27(1): 47

7 Greer A L, Ma E. MRS Bulletin[J], 2007, 32: 611

8 Sampath V. Materials and Manufacturing Processes[J], 2007, 22: 1532

9 Anthony L, Fultz B. Journal of Materials Research[J], 1989, 4: 1132

10 Huang Y J, Shen J, Sun Y et al. Materials and Design[J], 2010,
$31: 1563$

11 Huang Y J, Shen J, Sun J F. Applied Physics Letters[J], 2007, 90 8191

12 Wang M L, Hui X D, Feng Q et al. Rare Metal Materials and Engineering[J], 2013, 42(11): 2217

13 Suo Z Y, Song Y L, Qiu K Q. Rare Metal Materials and Engineering[J], 2014, 43(9): 2289 (in Chinese)

14 Yuan X B, Chen B, Liu F S et al. Rare Metals[J], 2014, 33(6): 652

15 Tariq N H, Akhter J I, Hasan B A et al. Journal of Alloys and Compounds[J], 2010, 507: 414

16 Wang W H. Progress in Physics[J], 2013, 33: 177 (in Chinese)

17 Hofmann D C. Journal of Materials[J], 2013, 13: 517904

18 Wei R, Chang Y, Li Y F et al. Materials Science and Engineering $A[\mathrm{~J}], 2013,587: 233$

19 Johnson W L. MRS Bulletin[J], 1999, 24: 42

20 Wei R, Yang S, Chang Y et al. Materials and Design[J], 2014, 56: 12

\title{
预变形退火对钛基非晶复合材料力学性能的影响
}

\author{
赵燕春 $^{1,2}$, 马文龙 ${ }^{1,2}$, 赵志平 ${ }^{1,2}$, 黄明源 ${ }^{1,2}$, 寇生中 ${ }^{1,2}$, 李春燕 ${ }^{1,2}$, 袁子洲 ${ }^{1,2}$ \\ (1. 兰州理工大学 省部共建有色金属先进加工与再利用国家重点实验室, 甘肃 兰州 730050) \\ (2. 兰州理工大学温州原阀工程研究院, 浙江 温州 325105)
}

摘 要: 采用磁悬浮熔炼-水冷铜模吸铸法制备出 $\mathrm{Ti}_{40} \mathrm{Ni}_{40} \mathrm{Cu}_{20}$ 非晶基复合材料板状试样, 通过压力试验机对试样进行不同程度的预压缩, 然后在 $150{ }^{\circ} \mathrm{C} 、 30 \mathrm{~min}$ 下退火, 利用金相、 $\mathrm{X}$ 射线衍射 (XRD)、扫描电镜（SEM）研究了预变形退火工艺对合金微观组织和力学性能 的影响。结果表明: 奥氏体相在外力作用下发生马氏体相变, 形变诱导相变加之退火释放残余热应力从而对非晶基体起到增强增韧的作 用。随着预变形程度的增加, 马氏体相和奥氏体相均增加, 而马氏体相增加地更快, 复合材料的屈服强度提高, 塑性减小, 塑形阶段预 变形能够实现屈服强度可控。

关键词：Ti 基非晶复合材料；力学性能；塑性

作者简介: 赵燕春, 女, 1984 年生, 博士, 兰州理工大学省部共建有色金属先进加工与再利用国家重点实验室, 甘肃 兰州 730050 , E-mail: yanchun_zhao@163.com 